\title{
Effects of the Bologna Process \\ on Quality Assurance Regimes \\ in the Post-Soviet Space: Isomorphism \\ and Path Dependencies in Moldova, \\ Russia, and Kazakhstan
}

\author{
Lukas Bischof
}

\section{Introduction}

\section{The Global Context}

When the Soviet Union broke apart in 1991, Central and Eastern European countries such as Russia, the newly independent republics of the Baltics, the Caucasus, and Central Asia needed to redefine their political, cultural, and economic orientation vis-a-vis each other and the world (Silova 2011a). A global and a European trend can be observed in these developments: Since the late 1990s, both Eastern and Western European HE systems have become increasingly embedded in a transnational environment which promoted changes to traditional governance structures of their higher education systems in the spirit of New Public Management (Leišyte et al. 2006). By the 1990s, virtually all Western European countries were implementing reforms aiming at transforming HEIs into "complete organisations" (Hüther and Krücken 2007, p. 28) and were moving from a "state control" model to a "state supervising" model (Goedegebuure et al. 1993) in which the state is steering from a distance (Marginson 1997; Meek et al. 1996). While highly heterogeneous themselves, reforms generally aimed at delegating greater organisational, financial, personnel and academic autonomy to the leadership of HEIs and at using competition and markets as steering mechanisms (e.g. through the use of project funding or through the promotion of student choice based on league tables and rankings). Direct state control over operations was eased while, at the same

\author{
L. Bischof (ه) \\ Higher School of Economics, Moscow, Russia \\ e-mail: info@lukasbischof.eu \\ L. Bischof \\ University of Leipzig, Leipzig, Germany \\ (C) The Author(s) 2018
}

A. Curaj et al. (eds.), European Higher Education Area: The Impact of Past and Future Policies, https://doi.org/10.1007/978-3-319-77407-7_6 
time, more explicit standards and performance measures were introduced, which placed greater emphasis on outputs vis-a-vis processes.

These policies were promoted globally by international organisations like the OECD, UNESCO and the World Bank to such a degree that a new "global model" has been said to now dominate the international discourse on higher education governance (Baker and Lenhardt 2008). The same organisations promoted these reforms as parts of the "Post-Socialist Reform package" in former socialist countries (Silova and Steiner-Khamsi 2008). They have become part of official policy discourse in almost all countries of the region, if not necessarily in practice, alongside privatisation, marketization of financing, stakeholder governance, and standardisation of student assessment (Silova 2005).

\section{European Influence in Higher Education in the Post-Soviet Space}

In parallel to global trends, the influence of European Integration grew visibly since the early 1990s when the Baltics states and other EU accession countries began participating in a wide range of EU-funded educational programs designed to prepare them to join the EU. In 1999, 29 European countries signed the Bologna declaration. The Bologna Process continued to extend into the Post-Soviet space when Russia joined the Bologna Process in 2003, the rest of Eastern Europe in 2005, and Kazakhstan in 2010. By 2017, even non-signatory and non-eligible states like Kyrgyzstan, Tajikistan, and - at least on the rhetorical level — Uzbekistan, have started implementing Bologna-inspired reforms of their own. A multitude of EU-supported policy and cooperation platforms such as TEMPUS projects, Erasmus Mundus cooperation, the EU-Central Asia Education Initiative, and activities within the "Eastern Partnership" with Armenia, Azerbaijan, Belarus, Georgia, Moldova, and Ukraine have provided high-level meetings, HEI cooperation projects, technical working groups, national level dialogue, and funding promoting the action lines of the Bologna Process in these countries.

Quality assurance (QA) gained a particular prominence within the Bologna Process with the development of the European Standards and Guidelines for Quality Assurance (ESG). The ESG represent a set of guidelines on internal and external quality assurance of HEIs and their study programs. A key principle of the ESG is autonomy: HEIs are primarily responsible for the quality and that Quality assurance agencies (QAAs) should be organisationally independent and operate without third-party influence such as from HEIs, governments and other stakeholder organisations (ENQA 2005, 2015). Substantial compliance with the ESG has become a prerequisite for QAAs to become members of ENQA, the European association of QAAs; and EQAR, the European Quality Assurance Register, which is intended to promote trust and cross-border cooperation in quality assurance across the European Higher Education Area (EHEA). Both memberships are highly coveted among national governments and QAAs.

Within my Ph.D. thesis conducted between 2014 and 2017 at the University of Leipzig (Bischof, under review), I have studied the changing governance of higher 
education systems in Post-Soviet countries, applying the "glonacal agency heuristic" (Marginson and Rhoades 2002) to identify the global, regional, national, and local driving forces and path-dependencies, which have shaped the development of three distinct governance frameworks from their common Soviet origins. In this paper, I will give an overview of the developments in quality assurance in the three Post-Soviet countries Russia, Moldova, and Kazakhstan, focusing on the role the Bologna Process has played in the complex interplay of global, regional, and national forces shaping the systems of quality assurance in the Post-Soviet space.

\section{Three Country Cases}

\section{Russia}

In Russia, in higher education as in other areas of state and society, the 1990s were a period of decentralization, liberalization, and marketization (Adrian et al. 2000; Bain 2003). The increase in university autonomy compared to the Soviet era was enormous: Appointment of rectors by the state was replaced with elections by academic councils. HEIs received the right to enrol students on a tuition-fee basis and to open new study programs. HEIs received considerable financial autonomy and became free to define their internal organisation, to employ their own staff, to set their own salaries, to rent and lease assets, and to establish branches campuses (Beliakov et al. 1999). Because of the budget contractions during the 1990s, however, the majority of HEIs used their new organisational autonomy mainly for economic survival. As a former vice-minister for education remembered in a personal communication, the spirit of the 1990s was "We cannot give you money, but we can give you freedom".

In order to assure the basic quality of more autonomous HEIs, as well as to maintain a unified educational space in Russia, a set of State Educational Standards (SES) were developed which defined common standards for structure and contents of study programs. A system of State licensing, attestation, and accreditation was established to control and certify that HEIs complied with these standards. This meant that the QA system changed from a model of state control and inspection to one based on regulation, something that had never existed in Russia previously (Motova and Pykkö 2012). Under the new system, licensing verified whether an HEI had sufficient resources (premises, equipment, information and library resources, or teaching staff) to carry out educational activities. Attaining a license meant that HEIs were authorized to deliver instruction and could benefit from certain tax benefits. Attestation consisted of verifying that graduates' performance was on par with SES. Lastly, accreditation granted the accredited institution the right to award nationally recognized state diplomas and to participate in state budget funding and exempted its male students from obligatory military service. All 
procedures were administered by a Department of Licensing, Accreditation, and Attestation within the Ministry of Education ${ }^{1}$ (MoES) with a plethora of specialized centres under its purview. Decisions were taken by an Accreditation Board composed of heads of HEIs, and representatives of associations of HEIs and sectoral ministries (Chistokhvalov 2007).

\section{Turning Towards Europe}

In the beginning of the 2000s, the government began to reassert itself as an actor in the higher education system. Rising oil prices and the ruble depreciation of 1998 had laid the basis for rapid economic growth. Along with reforms in the economy, the state re-identified education as a priority (Semyonov and Platonova 2017). The introduction of a centralized national admission exam (the so-called Unified National Exam) was launched to combat corruption in admission and support student mobility.

The year 2000 marks a turning point also for the QA system in Russia which opened itself to European influences in higher education. Attestation and accreditation were merged into a single procedure. Accreditation became compulsory for all HEIs (before, it had been only for state HEIs), and the MoES began organising a competition for the best quality management systems within universities (Forrat 2012). After Russia joined the Bologna process in 2003, Russia launched a number of legislative initiatives and regulations regarding the introduction of a two-tier system of degrees, introduced a new generation of educational standards granting greater freedom to HEIs to define their own contents of study programs. There was also continued support for the development of internal quality management, such as a "Coordination Council on Quality Provision" which in 2005 issued recommendations on internal quality management systems (Motova 2015). The effectiveness of internal quality management systems became one of the indicators for accreditation (Forrat 2012). During the period between 2002/2003 and 2009, related to Russia's ascension to the Bologna Process, proposals within the MoES were continuously being discussed that independent accreditation agencies should be certified by the state and their accreditation be recognized as equivalent to state accreditation. An incorporated "guild of experts" received support from the state oversight body for education Rosobrnadzor to conduct trainings for reviewers, and independent QAAs were given signals that they might be recognized by the state replacing state accreditation.

The development of an independent accreditation system as it has become the norm (if far from ubiquitous) in the European Union, however, never came to fruition in Russia. On the contrary, since 2004, the state began to reassert itself as the steering and intervening actor.

\footnotetext{
${ }^{1}$ The Ministries of Education and that of Science were merged in 2004.
} 
The new framework for quality assurance which successively emerged between 2004 and 2017 was guided by the idea that public resources in HE should be concentrated on so-called "pivot points" (tochki rosta), a smaller number of high-quality HEIs while the overall number of HEIs should be radically reduced. In interviews Fursenko gave in 2004 and 2005, he argued that instead of the then over 1000 HEIs, there should be 20-50 leading HEIs and 150-200 HEIs of second rank to provide highly qualified specialists to the economy (Fedyukin and Froumin 2010). This new system rested on support and incentives through a redistribution of funding, on the one hand, stricter state monitoring of performance indicators, state inspections, closures and mergers of HEIs, on the other, and a redistribution of public funding from the weaker HEIs to the stronger ones.

The first pillar consisted of support for leading universities. Since 2005, a series of support programs were launched to support Federal Universities (in 2005/2006), National Research Universities (in 2008), world-class research universities (program "5-100", in 2012) and flagship universities (in 2016). Participants were chosen in an open competition ${ }^{3}$ and were allocated considerable additional funding but at the price of losing the right to elect their own rectors, who were appointed by the government (Froumin and Povalko 2014). They also had to submit to a regime of regular evaluations of their implementation progress towards their HEI's development program. HEIs which do not meet their own goals can be expelled from the program, although so far none ever was.

The second pillar of the strategy rests on tighter control and intervention by the state. In 2009, by decision of the new head of Rosobrnadzor, a staff reshuffle took place at the National Accreditation Agency (Rosakkredagenstvo), and almost all of the staff left due to disagreements over the role and functioning of the agency. The centralization was completed when the seat of Rosakkredagenstvo was moved from Yoshkar-Ola to Moscow in 2011 where the agency now shares offices in the same building with Rosobrnadzor. At the same time, Rosobrnadzor received the right to conduct unannounced inspections of HEIs at any time as well as the power to revoke a license of a university, which earlier could have been done only by a court decision. This change converted the system of licensing and accreditation from fairly bureaucratic, yet predictable process into a powerful instrument of state steering and control in the hands of Rosobnadzor. As a high-ranking staff member of Rosobrnadzor explains its significance:

The assessment and accreditation of HEIs are now a prerogative of Rosobrnadzor. This is a
very strong instrument of power: You give to some, you don't give to others. [...] It is clear
that the loss of a license or of accreditation is a really big loss [..] Therefore, there is an
infinite number of issues related to the objectivity of decision-making" [...] Now there will
be a trial of the European university, a good university. They will sue Rosobrnadzor. [.]
There were many attempts [to close a university], but earlier we decided these issues
through the courts, as we could not decide on accreditation ourselves. [..] The courts are in

\footnotetext{
${ }^{2}$ The designation " $5-100$ " refers to the program's goal of at least five Russian universities being represented among the top one hundred in global university rankings by 2020 .

${ }^{3}$ Except for the Federal universities.
} 
favour of the government, but this is a long, tedious process, a large machine which accompanies these things. [..] Now it is easier: Rosobrnadzor cancels [accreditation] and [the universities] need to go to court and try to protest [...] For many this already means a loss of reputation, a loss of students, and you will go to court? You already have nothing. ${ }^{4}$

With the ground thus laid, the so-called "effectiveness monitoring" (monitoring effektivnosti) was launched in 2012 with the purpose to identify HEIs with low performance based on centrally collected indicator data ${ }^{5}$ (Froumin et al. 2014). HEIs which did not meet performance standards set by the MoES were labelled as 'ineffective' and subsequently investigated by Rosobrnadzor. If sufficient shortcomings are found, HEIs can be merged with other institutions, partially restructured or lose their license or accreditation altogether and have to close.

Finally, a third pillar can be seen in the new mechanism of allocation of state funding for HEIs that was introduced in 2013. HEIs which perform well on a set of state-defined performance indicators (similar to the ones used in the efficiency monitoring) are now getting a preferential allocation of state-funded study places. This puts further pressure on weak HEIs and increases their risk of being investigated by Rosobrnadzor (pillar two). Since 2012, decisions by Rosobrnadzor have resulted in mergers and liquidations of a large number of HEIs and an even higher number of branches. In 2014 alone, Rosobrnadzor closed 357 HEIs and branches. In the first half of 2015, 151 Russian HEIs and branches had their license withdrawn, 34 lost their accreditation. ${ }^{6}$

\section{Moldova}

During the early Post-Soviet regulatory vacuum, there was no formal quality assurance procedure in Moldova. Soviet regulations were quickly abolished by the Moldovan government, without a coherent strategy to replace them. As Padure (2009) quotes a policymaker of the time "...the first years of independence represented a period of legal nihilism in education, when Soviet regulations were declared invalid in the Republic of Moldova, while local regulations were missing". As a consequence, the number of public and private HEIs mushroomed, often to the detriment of their quality (Tofan and Bischof 2017).

Only during the second part of the 1990s, did the state try to reassert its regulatory role with the first law on Education (1995), the Law on the Evaluation and Accreditation of Educational Institutions (1997), and the Law on the Endorsement

\footnotetext{
${ }^{4}$ Personal interview.

${ }^{5}$ Indicators relate to quality of student intake, teaching effectiveness, research, faculty, infrastructure, finance, labour market outcomes of graduates, and internationalisation.

${ }^{6}$ https://www.ucheba.ru/article/1041.
} 
of the Regulations on the Evaluation and Accreditation of Educational Institutions (1999). Prior to 1999, the assessment and accreditation of educational institutions were seen as a prerogative of the MoE which had failed, however, to establish transparent criteria and procedures. The steep increase of the number of private HEI -which were, not rarely, even using the same physical spaces, learning resources, and teaching and administrative staff of public HEIs - was seen as a sign that the system was ineffective or even corrupt (Toderaş 2012).

The law of 1997 established a quality assurance system through state control and accreditation similar to the Russian model. Between 1997 and 1999, CNEAA was supported by the US-embassy with study trips and consultations by US experts ${ }^{7}$ and developed a peer-review system for the accreditation of HEIs and study programs based on international practice. In 1999, the National Council for Academic Evaluation and Accreditation (Consiliul Naţional de Evaluare şi Acreditare Academica $-C N E A A$ ) was established as the Quality Assurance Agency for study programs. While the process of accreditation was formally independent, however, final accreditation decisions needed to be confirmed by the MoE and the government. This led to a series of conflicts with influential interests over the non-accreditation of certain study programs.

The CNEAA had started to conduct its first accreditations when in 2001 the communist party came into power and the new minister Gheorghe Sima abolished it as of August 2002. The former head of CNEAA relates this to their independent stance:

We began to critically evaluate their work [..], we criticized the ministry in that it did not fulfil certain [of its] tasks. Well, they did not like this, they wanted the council [CNEAA] to be subordinated to them, as a unit of the ministry. And that the minister could give it orders "do this, or do that". This did not happen, and in principle, because of it, they completely transformed us. Not one [of the staff of CNEAA] was kept on the new team [at the ministry $]^{8}$

All of its functions were transferred to the MoE. Nevertheless, the procedures and criteria CNEAA had developed for the accreditation of study programs and HEIs remained in place after 2002, although the government gained more immediate influence over final decisions which it did exercise in a number of cases in which accreditation was granted against the results of the evaluation. Nevertheless, the Directorate of Higher Education Accreditation conducted evaluations and accreditations from 2002 until 2008, bringing a degree of order back into the higher education system. During this time, a number of private HEIs were closed down or voluntarily ceased operations due to stricter accreditation requirements. All public HEIs retained their accreditation.

In 2003 Moldova began to prepare to join the Bologna Process, which officially took place in 2005 . This required changes to a number of laws, structural reforms in higher education, a new nomenclature of study programs and a number of other

\footnotetext{
${ }^{7}$ Personal interview with CNEAA's founder.

${ }^{8}$ Personal interview.
} 
changes, among them an orientation of the quality assurance system at the European Standards and Guidelines for Quality Assurance (ESG). In 2006, trying to adapt to the ESG and responding to a certain pressure from the Council of Europe and the European Commission to separate the MoE from evaluation, authorization and accreditation of HEIs, the Moldovan government decided to close the department for quality assurance within the $\mathrm{MoE}$ and to transfer its responsibilities to a newly created Agency for Assessment and Evaluation (Agenția de Evaluare şi Examinare-AEE), a public institution under the remit of the MoE. While already charged with a very wide range of responsibilities, this agency was burdened with additional tasks for which it was ill-prepared, such as the organisation and administration of examinations in secondary education, or the organisation of science Olympiads and national and international competitions. As a consequence, the communist government had difficulties finding a director who was knowledgeable in both secondary and tertiary education, willing and capable to run the agency, as well as politically opportune. In the end, the agency only occupied itself with non-tertiary education, and the MoE continued to conduct accreditations itself.

By 2008, however, it had become obvious to the Communist party that they would lose the next elections and they would lose their influence in the MoE. Among other decrees, in November 2008, the Government issued a decree creating the Quality Assurance Agency (Agenţie de Asigurare a Calităţii-AAC) and approved a set of new regulations. The objective was to create a transparent, integrated quality assurance system for both secondary and tertiary education. Possibly due to the lack of time for its elaboration, instead of clarity, the concept for the new agency created even more confusion and uncertainty among its stakeholders. The QA processes foreseen for higher education and those for primary, secondary and upper secondary education were not clearly differentiated. Toderaş (2012) claims that in addition to these design flaws, some structures and departments were created not to best serve the foreseen processes, but to guarantee the influence of certain individuals and their special interests within the future structures.

When the communist party lost their parliamentary majority to the Alliance for European Integration, the Department of Accreditation within the MoE had been closed, but the new agency had not been founded. Without any legal procedure in place, study programs which were established after 2008 could not undergo the mandatory periodic evaluations and accreditations and were, therefore, operating in a state of semi-illegality (Ciurea et al. 2012). As one former ministry official remembers:

In the context of the Bologna Process we studied the experience of other countries and it was clear that within the framework of the MoE it is not good to have such a structure. [...] This is why they closed it within the Ministry, because it did not correspond with the tendencies in Europe. It was clear that we needed to create another structure [...] but, unfortunately, they closed one but did not establish the other ${ }^{9}$

${ }^{9}$ Personal interview. 
For the new government, integration into the European Higher Education Area (EHEA) remained a priority, however, and having a functional QA system at institutional and country-level was seen as crucial not only for achieving this goal. Work on a new code of education began shortly after the elections. While all stakeholders were, in principle, in agreement that an agency for quality assurance and accreditation was urgently needed, disagreements between the Moldovan Rectors' Council, the Academy of Science and other interest groups in the parliament dragged the discussion out to almost four years. The frequent changes of ministers at the head of the MoE further complicated reaching a consensus. ${ }^{10}$ The first draft was published for debate in early 2010. Several times, a new version of the Code of Education was worked out by the Council of Rectors and the MoE, only to be sent to the parliament to be refused or changed.

During this process, the TEMPUS project "Development of Quality Assurance in Higher Education in Moldova" (QUAEM) ${ }^{11}$ (2012-2016) contributed to the development of the new QA system by conducting trainings and discussion sessions of different European models of internal and external QA, as well as pilot evaluations and accreditations by a German QAA. The new code of education was finally passed in 2014, providing the framework for the new quality assurance agency ANACIP. Its practical establishment, however, was a fraught journey: Rifts quickly appeared between the agency-to-be and the MoE on the structures, procedures and evaluation criteria. Limited funding, personal and institutional independences in a small country and political pressure from opponents like the Academy of Science still threaten its work as an independent agency.

\section{Kazakhstan}

In Kazakhstan, as in other Post-Soviet countries, the economic collapse and the disappearance of the central authority and funding from Moscow made the creation of state institutions the first order of business to assure the short- and mid-term survival of the educational system. A new legal framework was formulated in the laws "On Education" in 1992 and "On Higher Education" in 1993 which regulated the overall operations of HEIs (Brunner and Tillett 2007). These laws, along with other regulations and standards re-created the high degree of centralized curricular design and control that had existed under the Soviet regime and which HEIs were used to (Ahn et al. 2017). Accompanying state curricular standards, the government launched a ministry-controlled QA procedure which obliged all HEIs to receive a license to operate and undergo periodical attestation by the State. While the initial chaotic growth of HEIs and study programs had eschewed regulation, by 1996, the

\footnotetext{
${ }^{10}$ With Leonid Bujor, Mihail Șleahtițchi, and Maia Sandu, there were three different ministers of education between 2009 and 2012 alone.

${ }^{11}$ 530537-TEMPUS-1-2012-1-DETEMPUS-SMGR.
} 
vast majority of HEIs had been brought under the supervision of MoES (McLendon 2004). By 1999, a highly centralized and detailed system of standards and control of study programs was in place for all subjects.

In 1999, the system was further centralized through the introduction of a Unified National Test for university admissions and a voucher-based system of state financing for HEIs. This way, the quality of students entering HE should be increased, corruption eradicated, and incentives created for HEIs to become as attractive as possible for students. Both reforms had been inspired partially by Russian developments but were implemented much more swiftly. While this system improved the quality of top-tier HEIs, there still remained a large segment of HEIs which fully depended on tuition fees and pursued a strategy of low-tuition, low-quality study programs, which in some cases amounted to little more than diploma-mills. The period between 2000 and 2004 was marked by a series of state measures to eradicate low-quality HEIs. In 2001, the first attempt to combat these was to introduce a system of state accreditation, which was based on an assessment of quantitative indicators (Kalanova 2014). The new methodology was launched prematurely, however, as neither standards nor procedures had been developed yet. Within the first three days, 59 universities had been officially accredited. Following heavy criticism of the system from the academic community as non-transparent and ultimately pointless exercise, in 2002, state accreditation was suspended for almost a decade. Instead, from January 2002, the MoES began to conduct a series of inspections of HEIs. Until 2003, 166 HEIs were controlled, of which 12 HEIs and 32 branches were closed down, and 170 licenses for study programs were withdrawn from 42 HEIs and 75 HEIs and 64 branches had their licenses suspended for different periods of time (Lyal'kina and Kanafina 2016). Later, branches were made illegal altogether and a cap on the ratio of students enrolled in distance versus full-time education was introduced. Even though several HEIs had been forced to cease their operations, many little selective, low-tuition HEIs continued to operate. In order to expose and regulate such HEIs, in a following step, the MoES in 2003 introduced "Comprehensive National Mid-Term Tests" to be conducted at all HEIs after the second year of studies on the contents of the compulsory subjects foreseen by the state standards. Students who failed the test were not allowed to continue their studies to the third year (World Bank and OECD 2007). By 2003, a heavily regulated quality assurance system resting on detailed standards and top-down control was in place.

\section{The State Program of Education Development 2005-2010 and the Appearance of Accreditation}

By order of the President, the first State Program of Education Development in the Republic of Kazakhstan for 2005-2010 was passed in October 2004. ${ }^{12}$

\footnotetext{
${ }^{12}$ Presidential orders play a significant role in Kazakhstan, as they are binding orders to the government and its often-changing ministers.
} 
The overarching objective of the program was to adapt Kazakhstan's education system to international practices in many aspects. This concerned the structure of education (such as introducing 12-year pre-tertiary education and a three-tier structure of higher education), governance of higher education (introduction of cooperative governance and the expansion of autonomy for HEIs, the integration of external stakeholders into the governance of HEIs), and the participation in international studies such as PISA, TIMSS, CIVIC, SITES, LES. Regarding quality assurance, it called for an overhaul of external and internal quality assurance and the participation in international networks of quality assurance agencies such as ENQA, and INQAAHE. The SPED 2005-2010 outlined for the first time an integrated perspective on the "national system of quality assessment in education" which structured the existing instruments of quality assurance (licensing, state attestation, the UNT and intermediate state control) to which independent accreditation, internal quality management were to be added (Kalanova and Omirbayev 2009). Quality management systems and institutional and specialized accreditation were explicitly related to "implement[ing] the key principles of the Bologna declaration and the WTO" (SPED 2005-2010).

The international dimension of this reform program cannot be overstated. According to one of the authors of the program, the SPED "...promoted HEI to international standards, and in particular to European ones. [...] It created a powerful impetus and created the preconditions for the realization of the action lines of the Bologna Process. [...] It was important to do this so that we would be noticed and understood in Europe and the world."13 Implementing the SPED, a National Accreditation Centre was founded under the MoES to develop a new methodology for accreditation, which began to develop its own standards based on American QAAs and the ESG. In 2007, accreditation was introduced in the law on education as a voluntary procedure to be conducted according to the standards of the accreditation agency carrying it out. This allowed NAC to instantly start working on the basis of the ESG without waiting for the government to develop their own set of standards and created an important precondition for the independence of Quality Assurance agencies in Kazakhstan. Thanks in part to the changes in study structures and quality assurance reforms of the SPED 2005-2010, on March 12, 2010, Kazakhstan became the first Central Asian Republic to sign the Lisbon Convention and become the forty-seventh member of the Bologna Process (BP).

As part of the efforts to align Kazakhstan with international practices in higher education, a review of Kazakhstan's education system was commissioned from the World Bank and OECD (2007) which made a strong case for further reforming the system of higher education, investing in quality, and decentralizing the system of bureaucratic governance. In 2010, the next "State Program of Education Development in the Republic of Kazakhstan" was passed (SPED 2011-2020), which called for independent accreditation to replace state accreditation and

\footnotetext{
${ }^{13}$ Personal interview.
} 
attestation by non-commercial, non-government accrediting agencies, which would be listed members in a register of recognized accreditation bodies. The absence of independence had been criticized in several external reviews (World Bank and OECD 2007; Raza 2009). The process of state attestation had also been receiving a lot of criticism from the academic community for being both too inflexible and indicator-oriented as well as for being conducted in the spirit of distrust and control. Within the MoES and the responsible committee for control in education, however, there was a strong reluctance to let go of these instruments of state control. During the preparation of the SPED, the President himself held several meetings where he urged all ministries to reduce the amount of oversight-related controls and the number of inspections in their areas. This top-down push, in concert with the international models and advice, was instrumental in the subsequent policy changes. As a former senior official from the MoES describes the impact of the Bologna Process on the development of independent accreditation:

As a country which joined the Bologna Process and took upon itself the responsibility to correspond to these criteria, we started to reform our system of quality assurance in accordance with these requirements. As you have seen, as the system changed from government accreditation to independent accreditation which corresponds to European standards. If we had not been in the Bologna Process, of course we would have said, "oh no, we will do it our way ${ }^{14}$

In 2008, the first Independent Kazakhstan Quality Assurance Agency for Education (IQAA) had already been founded by the former head of NAC and, when NAC ceased conducting accreditations in 2011, part of its staff founded the Independent Agency for Accreditation Rating (IAAR) as the second non-governmental quality assurance agency after IQAA. The 2011 law on education also included powerful incentives for HEIs to undergo independent accreditation (Sagintayeva et al. 2014): HEIs that passed institutional and program accreditation in recognized accreditation agencies would be exempt from state attestation for the period of accreditation. More significantly, only accredited HEIs would be allowed to enrol state-funded students.

The move from state attestation to independent accreditation represented, for the first time since independence, a transfer of powers from the MoES to bodies not under its direct control. It went even further than most EU-countries, as it recognized national reviews as well accreditations conducted by international agencies. As one representative of a quality assurance agency comments:

Kazakhstan in this respect is at the forefront of probably the entire planet. Even among European countries you hardly find a country which has completely opened its market for international agencies. You see, in 2011 when we conducted the reforms, we implemented the Bologna Process [...] There were recommendations that there should be an independent agency and the system should be open and so our government opened the system so that it would be competitive, that there should be competition on this market. Maybe we approached the [Bologna] ministerial recommendation a bit overeagerly, but on the other

\footnotetext{
${ }^{14}$ Personal interview.
} 
hand, it is good, even for national agencies, because for us this is an incentive to develop because we have strong international competition ${ }^{15}$

The degree of resistance against this change should not be underestimated, however. When in 2015, according to the SPED, accreditation should have fully replaced state attestation, the MoES initially submitted a draft law for state attestation to remain in place while accreditation would be uncoupled from financing in any way. A public conflict erupted between the Ak-Zhol opposition party and the minister of education over this issue. Finally, the authority of the presidential status of the SPED prevailed over the MoES's position, as non-implementation of independent accreditation would have implied a failure to implement a presidential order. ${ }^{16}$ Finally, a compromise was reached and from January 2017, state attestation was discontinued for the majority of HEIs. Licensing, intermediate testing and licensing controls remained in place as instruments of control within the purview of the MoES. This is not to say that the changes are all "locked-in". Attestation remains for some ministry-affiliated HEIs, and the quick succession of ministers looks unlikely to change, and the pace of legislative changes remains high as factions in parliament, government, QAAs and the HEI lobby for their interests and their vision of governance of the HE system.

\section{Conclusion}

After 25 years of transformations of higher education systems in Post-Soviet countries, the single Soviet model of higher education has evolved into fifteen unique national systems, shaped by economic, cultural, and political forces of national, regional (European) and global nature. On the one hand, it is visible that no country has been left completely untouched by the "global model" of HE governance. It has become clear that the Bologna process and the ESG principle of independent external accreditation have exerted a considerable isomorphic influence on quality assurance in all three Post-Soviet countries under analysis. On the other hand, the specific developments in quality assurance in the three countries illustrate clearly diverging trajectories, driven and influenced by different national forces:

- In Russia, during the 2000 s, there was a clear openness to adopting a "European" model of quality assurance; the support this movement enjoyed among the top echelons of the MoES and the Russian government as a whole was never sufficient to overcome the resistance within the state bureaucracy and parts of the higher education establishment. In 2009, adapting to the ESG ceased to be a relevant consideration altogether, as Russia developed its own

\footnotetext{
${ }^{15}$ Personal interview.

${ }^{16}$ Several personal interviews.
} 
governance model based on the three pillars of financial support, financial redistribution and administrative intervention. Independent accreditation continues to exist at the fringes of the system but demand remains low, and the agencies offering it have never come to play a significant role in the overall governance of the higher education system.

- In Moldova, the ascension to the Bologna Process did create a situation of "coercive isomorphism" insofar as the ESG provided a strong model of what kind of quality assurance system would have to be developed in order to become part of the European Higher Education Area (Toderaş 2012). Significant resources and support were made available, primarily by the European Union, to support policy convergence in Moldova. On the other hand, the often-changing political landscape in the country, political inter-dependencies of key actors, vested interests of the academic oligarchy, corruption in the HE system and the overall economic and financial difficulties of HEIs acted as powerful forces of inertia and resistance to any systemic change in quality assurance as in the overall governance of higher education (Ciurea et al. 2012). To what degree the new QAA will indeed be independent and successful in the long run, remains to be seen.

- In contrast, Kazakhstan, even though joining the Bologna Process much later than the other two countries, has become a type of "model student" of the Bologna Communiqués on QA. Not only did the country introduce independent accreditation, but also allowed international QAAs to operate on par with national agencies. Looking at the national factors underlying this apparent policy convergence, however, three stand out: Firstly, Kazakhstan did not have a strong entrenched higher education lobby rejecting reform that conflicted with past ideals. Secondly, a number of key experts in the MoES and the presidential administration, have lobbied for reform on accreditation and have succeeded to include it in the presidential development programs. Lastly, and most importantly, the president of the country has acted as a decisive proponent of reform (not only) in the sphere of higher education pushing for the adoption of international practices, inviting international organisations and pursuing membership in international bodies from the Bologna Process to the OECD. Presidential support for the state strategies for education development was undoubtedly a key factor in overcoming (or overruling) resistance and scepticism in the ministerial bureaucracy. This factor sets Kazakhstan apart also from other Central Asian countries, where "travelling policies" promoted by international organisations have increasingly clashed with the desire of policy-makers to maintain Soviet education legacies (Silova 2011b).

The review of the three countries makes it clear that mere surface "convergence" of policies ("e.g. the existence of independent accreditation agencies") hides a considerable diversity of actual practices. Considering national contexts, development trajectories, actors and formal as well as informal institutions is key to a deep understanding of the nature of institutional change and the necessary foundation for any form of sound policy advice. 


\section{References}

Adrian, Z., Bentabet, J., Vinokur, A., Linej, T., Planas, Z., Prohorov, Z., et al. (2000). Belaja kniga rossijskogo obrazovanija [White Book of Russian Education]. Moscow: MJeSI (Proekt Tasis "Upravlenie obrazovaniem").

Ahn, E. S., Dixon, J., \& Chekmareva, L. (2017). Looking at Kazakhstan's higher education landscape: From transition to transformation between 1920 and 2015. In H. Jeroen, S. Anna, \& F. Isak (Eds.), 25 Years of transformations of higher education systems in Post-Soviet countries. Reform and continuity. Basingstoke: Palgrave Macmillan.

Bain, O. B. (2003). University autonomy in the Russian federation since Perestroika. New York, NY [u.a.]: RoutledgeFalmer (Studies in higher education, dissertation series).

Baker, D. P., \& Lenhardt, G. (2008). The institutional crisis of the German research university. Higher Education Policy, 21(1), 49-64. https://doi.org/10.1057/palgrave.hep.8300178.

Beliakov, S., Lugachyov, M., \& Markov, A. (1999). Financial and institutional change in Russian higher education.

Brunner, J. J., \& Tillett, A. (2007). Higher education in Central Asia: The challenges of modernization (The World Bank, 68926).

Chistokhvalov, V. (2007). Bologna process national report Russian federation 2005-2007.

Ciurea, C., Berbeca, V., Lipcean, S., \& Gurin, M. (2012). Sistemul de învățământ superior din Republica Moldova în contextul Procesului Bologna: 2005-2011 Chișinău: Soros Foundation. Retrieved December 22, 2015, from http://www.soros.md/files/publications/documents/Studiu \%20Procesul\%20Bologna\%202005-2011.pdf.

ENQA. (2005). Standards and guidelines for quality assurance in the European higher education area. 20093 rd edition Helsinki. Retrieved from http://www.enqa.eu/wp-content/uploads/2013/ 06/ESG_3edition-2.pdf.

ENQA. (2015). Standards and guidelines for quality assurance in the European higher education area (ESG) Brussels, Belgium. Retrieved from http://www.enqa.eu/wp-content/uploads/2015/ 11/ESG_2015.pdf.

Fedyukin, I., \& Froumin, I. (2010). Rossiyskie vuzy-flagmany. Pro et Contra, May-June, 20-31.

Forrat, N. (2012). Authoritarianism and the market: The 'neoliberal' reforms in Russia's higher education. Retrieved from http://iippe.org/wp/wp-content/uploads/2013/06/Forrat-Authoritarianismand-the-Market.pdf.

Froumin, I., Kouzminov, Y., \& Semyonov, D. (2014). Institutional diversity in Russian higher education: revolutions and evolution. European Journal of Higher Education, 4(3), 209-234. https://doi.org/10.1080/21568235.2014.916532.

Froumin, I., \& Povalko, A. (2014). Top down push for excellence. In C. Ying, W. Qi, \& L. NianCai (Eds.), How world-class universities affect global higher education (Vol. 26, pp. 47-63). SensePublishers (Global perspectives on higher education).

Goedegebuure, L., Kaiser, F., Maassen, P., Meek, L., van Vught, F., \& de Weert, E. (1993). Hochschulpolitik im internationalen Vergleich. Eine länderübergreifende Untersuchung im Auftrag der Bertelsmann Stiftung Gütersloh: Bertelsmann Stiftung. Retrieved August 23, 2016, from http://tocs.ulb.tu-darmstadt.de/25127845.pdf.

Hüther, O., \& Krücken, G. (2007). Hierarchie ohne Macht? Karriere- und Beschäftigungsbedingungen als ,vergessene' Grenzen der organisatorischen Umgestaltung der deutschen Universitäten. In K. Georg, K. Anna, \& T. Marc (Eds.), Towards a multiversity? Universities between global trends and national traditions (pp. 27-40). Bielefeld, Piscataway, NJ: Transcript; Distributed in North America by Transaction Publishers (Science studies).

Kalanova, S. (2014). Higher education and quality assurance of higher education in the Republic of Kazakhstan.

Kalanova, S., \& Omirbayev, S. (2009). The national system and educational standards for higher education in the Republic of Kazakhstan: Analitical report (Natcionalnaya sistema i obrazovatelnyye standarty vysshego obrazovaniya v Respublike Kazakhstan: analitichesky doklad) (2nd ed.) Research center on the issues of quality in training specialists. 
Leišytè, L., de Boer, H., \& Enders, J. (2006). England-Prototype of the evaluative state. In K. Barbara \& L. Ute (Eds.), Reforming university governance: Changing conditions for research in four European countries (pp. 21-56). Bonn: Lemmens.

Lyal'kina, A., \& Kanafina, Z. (2016). Eksperimenty nad obrazovaniyem v Kazakhstane - ot zari nezavisimosti do nashikh dney [Experiments on education in Kazakhstan-from the dawn of independence to our days]. informbyuro. 25.04.2016.

Marginson, S. (1997). Markets in education. Sydney: Allen \& Unwin.

Marginson, S., \& Rhoades, G. (2002). Beyond national states, markets, and systems of higher education: A glonacal agency heuristic. In. High Education Policy, 43(3), 281-309.

McLendon, M. (2004). Straddling market and state: Higher education governance and finance reform in Kazakhstan. In P. H. Stephen \& J. D. Alan (Eds.), The challenges of education in Central Asia. Greenwich, Conn. Great Britain: Information Age Pub (International perspectives on educational policy, research, and practice).

Meek, V. L., Goedegebuure, L. C. J., Kivinen, O., \& Rinne, R. (1996). The mockers and mocked: Comparative perspectives on differentiation, convergence and diversity in higher education: Pergamon.

Motova, G. (2015). Три этапа развития аккредитации в России. In Аккредитащия в образовании.

Motova, G., \& Pykkö, R. (2012). Russian higher education and European standards of quality assurance. European Journal of Education, 47(1), 25-36. https://doi.org/10.1111/j.1465-3435. 2011.01505.x.

Padure, L. (2009). The politics of higher education reforms in central and eastern Europe: Development challenges of the Republic of Moldova (Ph.D. Thesis) University of Toronto, Toronto. Retrieved from https://tspace.library.utoronto.ca/bitstream/1807/19157/6/Padure_ Lucia_200911_PhD_thesis.pdf.

Raza, R. (2009). Examining autonomy and accountability in public and private tertiary institutions. Human Development Network: World Bank.

Sagintayeva, A., Bridges, D., McLaughlin, C., Mehisto, P., Drummond, M. J., Ayubayeva, N., et al. (2014). Development of strategic directions for education reforms in Kazakhstan for 2015-2020 (Diagnostic Report). Nazarbayev University Graduate School of Education. Astana, Kazakhstan. Retrieved from http://nur.nu.edu.kz/bitstream/handle/123456789/335/ DIAGNOSTIC\%20REPORT.pdf?sequence=1\&isAllowed $=\mathrm{y}$.

Semyonov, D., \& Platonova, D. (2017). Russia (Working Title). In J. Huisman, A. Smolentseva, \& I. Froumin (Eds.), 25 years of transformations of higher education systems in Post-Soviet countries. Reform and continuity. Basingstoke: Palgrave Macmillan.

Silova, I. (2005). Traveling policies: Hijacked in Central Asia. European Educational Research Journal, 4(1), 50-59. https://doi.org/10.2304/eerj.2005.4.1.5.

Silova, I. (2011a). Higher education reforms and global geopolitics: Shifting cores and peripheries in Russia, the Baltics, and Central Asia. Russian Analytical Digest, 97, 9-12.

Silova, I. (2011b). Introduction. In I. Silova (Ed.), Globalization on the margins: Education and postsocialist transformations in Central Asia (pp. 1-26). Charlotte, N.C.: Information Age Pub.

Silova, I., \& Steiner-Khamsi, G. (Eds.). (2008). How NGOs react: Globalization and education reform in the Caucasus, Central Asia and Mongolia. Bloomfield, CT: Kumarian Press.

Toderaș, N. (2012). Guvernanța sistemului de învățământ superior din Republica Moldova. cazul unei schimbări instituționale eșuate. Bucharest, Romania.

Tofan, A., \& Bischof, L. (2017). Higher education system dynamics and institutional diversity in Post-Soviet countries: The case of Moldova. In J. Huisman, A. Smolentseva, \& I. Froumin (Eds.), 25 years of transformations of higher education systems in Post-Soviet countries: Reform and continuity. Basingstoke: Palgrave Macmillan.

World Bank \& OECD. (2007). Higher education in Kazakhstan. Paris: OECD, [S.l.] World Bank (Reviews of national policies for education). 
Open Access This chapter is licensed under the terms of the Creative Commons Attribution 4.0 International License (http://creativecommons.org/licenses/by/4.0/), which permits use, sharing, adaptation, distribution and reproduction in any medium or format, as long as you give appropriate credit to the original author(s) and the source, provide a link to the Creative Commons license and indicate if changes were made.

The images or other third party material in this chapter are included in the chapter's Creative Commons license, unless indicated otherwise in a credit line to the material. If material is not included in the chapter's Creative Commons license and your intended use is not permitted by statutory regulation or exceeds the permitted use, you will need to obtain permission directly from the copyright holder.

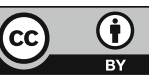

